\title{
Nitrogen and Phosphorus Retention and Excretion in Late-Gestation Dairy Heifers
}

\author{
S. R. Hill, ${ }^{\star 1}$ K. F. Knowlton, ${ }^{*}$ R. E. James, ${ }^{\star}$ R. E. Pearson, ${ }^{\star}$ G. L. Bethard,† and K. J. Pence* \\ *Virginia Polytechnic Institute and State University, Blacksburg 24061 \\ †G and R Consulting Inc., Wytheville, VA 24382
}

\begin{abstract}
The objectives of this study were to evaluate the effects of limit feeding diets containing concentrates or by-products in place of forages on manure and nutrient excretion in growing, gravid heifers. Eighteen Holstein heifers confirmed pregnant were grouped by due date and fed 1 of 3 diets ( $n=6$ per treatment) for the last 14 wk of pregnancy. Diets were high forage, fed ad libitum (HF); by-product based (BP), fed at the same rate as HF-fed heifers; or low forage (LF), fed at $86 \%$ of the HF diet. Diets were designed to supply equal quantities of $\mathrm{P}, \mathrm{N}$, and metabolizable energy. Total collection of feces and urine was conducted in wk 14, 10, 6 , and 2 prepartum. The HF ration was $90.7 \%$ forage, $13.7 \%$ crude protein $(\mathrm{CP})$, and contained orchardgrass hay, corn silage, corn grain, soybean meal $44 \%$, and a vitamin-mineral premix. The BP diet was $46.2 \%$ forage and $14.0 \% \mathrm{CP}$, with $70 \%$ of the grain mix space replaced with soybean hulls and cottonseed hulls in a 1:1 ratio, with intake limited to $93 \%$ of the dry matter intake (DMI) of HF. The LF ration was $45.3 \%$ forage and $17.8 \%$ $\mathrm{CP}$, with intake limited to $86 \%$ of the DMI of HF. The effect of diet was analyzed with repeated measures, using preplanned contrasts to compare $\mathrm{HF}$ with $\mathrm{BP}$ and LF with HF and BP. As designed, heifers fed HF and $\mathrm{BP}$ had greater DMI than the heifers limit-fed LF, and there was no effect of diet on average daily gain or BW. Intake and digestibility of $\mathrm{N}$ were lower, and fecal $\mathrm{N}$ excretion was higher, in heifers fed HF and BP than heifers fed LF. Mean feces excretion on both a wet and dry basis was greater for HF heifers compared with BP heifers and less for LF heifers than for $\mathrm{HF}$ and $\mathrm{BP}$ heifers. Despite differences in urinary output, diet had no effect on urea $\mathrm{N}$ excretion, but there was a trend for heifers fed $\mathrm{HF}$ and $\mathrm{BP}$ rations to excrete less urinary $\mathrm{N}$ compared with those fed LF. Compared with HF and BP heifers, LF heifers tended to have lower fecal $\mathrm{P}$
\end{abstract}

Received January 29, 2007.

Accepted August 10, 2007.

${ }^{1}$ Corresponding author: srhill@ncat.edu excretion and had higher urinary $\mathrm{P}$ excretion. Measured manure and urine excretion from heifers fed LF was greater than current American Society of Agricultural and Biological Engineers values, whereas heifers fed HF excreted less manure and urine than predicted. Heifers achieving similar rates of gain from diets differing in forage, grain, and by-product content excreted widely varying quantities of manure.

Key words: manure excretion, dairy heifer growth, nutrient excretion

\section{INTRODUCTION}

With the changes in the definition of concentrated animal feeding operations and the inclusion of smaller farms, nutrient management planning is a priority for livestock producers (833-F-02-009; US Environmental Protection Agency, 2002). These revised regulations do not only affect dairy producers with lactating cows; they also affect heifer growers, calf ranchers, and any facility in which water may come in contact with animal waste as it exits the farm. An abundance of information is available on manure nutrient excretion from lactating cows (St-Pierre and Threan, 1999; Knowlton et al., 2001; Haig et al., 2002; Kebreab et al., 2002; Davidson et al., 2003), but data on heifer nutrient excretion are scarce.

Diets fed to dairy heifers vary widely, and fiber and energy concentration and source can affect growth and digestibility and excretion of both $\mathrm{N}$ and $\mathrm{P}$. Raising dairy heifers is the second largest expense on a dairy farm (Heinrichs, 1993), and enabling heifers to reach puberty and pregnancy faster to become productive members of the herd is economically beneficial to the producer. Altering the forage-to-concentrate ratio to increase concentrate intake can improve prepubertal ADG and help producers grow heifers to ideal breeding weights faster (Zanton and Heinrichs, 2006). Our objectives were to evaluate the effects of limit feeding diets containing concentrates or by-products in place of forages on manure and nutrient excretion in growing, gravid heifers. 


\section{MATERIALS AND METHODS}

\section{Animals and Diets}

Eighteen Holstein heifers ( $494 \pm 34 \mathrm{~kg}$ and $21.3 \pm 1.4$ mo of age at the beginning of the experiment) were fed treatment diets for $112 \mathrm{~d}$ during late gestation. Heifers were grouped according to due date and were assigned randomly to 1 of 3 treatment diets formulated to provide equal intakes of $\mathrm{P}, \mathrm{N}$, and $\mathrm{ME}$. Heifers were housed in 3 pens in a partially open barn. Each pen had 6 heifersized Calan gates (American Calan, Northwood, NH) and was bedded with wood shavings. All heifers were fed the high-forage (HF) ration for 1 wk while being trained to eat from Calan gates and to become accustomed to human interaction. Heifers were then acclimated to their respective diets for at least $14 \mathrm{~d}$ prior to the first collection period. The HF, by-product (BP), and low-forage (LF) diets were formulated to contain 90.7, 46.2, and $45.3 \%$ forage, respectively. All diets contained a mixture of chopped orchardgrass hay and corn silage as the forage source. All ration ingredients were mixed in a Calan Data Ranger for approximately $5 \mathrm{~min}$ and were delivered to heifers as a TMR once daily at $1300 \mathrm{~h}$. Water was added to all diets to increase palatability. Appropriate amounts of water were added to each diet to achieve $50 \% \mathrm{DM}$. The heifers fed the HF diet were allowed ad libitum intake and feed offered was increased daily if refusals were less than $10 \%$. The concentrate portion of the HF diet was composed of soybean meal, mineral mix, and calcium carbonate (Table 1). The BP diet was formulated to be similar in forage content to the LF diet, but to contain higher fiber than the LF diet because of inclusion of cottonseed hulls and soybean hulls in a 1:1 mixture, which was blended with corn, soybean meal, and mineral mix. Feed offered to the heifers fed the BP diet was $93 \%$ of the feed offered to HF heifers. The concentrate portion of the LF diet was composed of corn, soybean meal, and mineral mix; feed offered was limit fed at $86 \%$ of the DMI of the HF heifers. This experiment was conducted under approval of the Virginia Tech Animal Care and Use Committee.

\section{Sample Collection}

Total collection of feces, urine, and feed refusals was conducted in wk 14, 10, 6, and 2 prepartum, based on expected calving date. Heifers were housed in groups, but were fed individually via Calan doors throughout the study, and moved to individual stalls for the 5-d collection period. On d 1 of each collection period, a sterile Foley catheter (22 French, 75 cc, C. R. Bard Inc., Covington, GA) was placed in the urethra for total collection of urine. Dry matter intake $(\mathrm{kg} / \mathrm{d})$ did not
Table 1. Ingredient and nutrient composition of 3 treatment diets fed to Holstein heifers

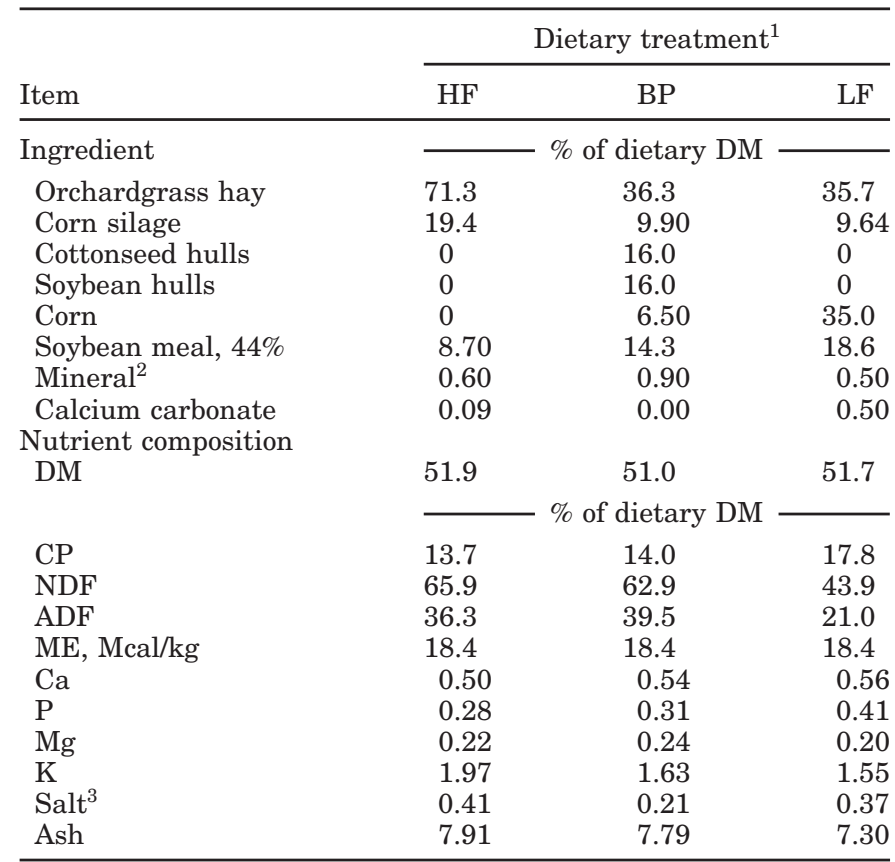

${ }^{1} \mathrm{HF}=$ high forage; $\mathrm{BP}=$ by-product; $\mathrm{LF}=$ low forage.

${ }^{2}$ Mineral $=4.5 \% \mathrm{CP}, 0.2 \%$ fat, $14.6 \% \mathrm{Ca}, 7.1 \% \mathrm{P}, 20.3 \% \mathrm{Na}, 22.4 \%$ $\mathrm{Cl}, 0.0 \% \mathrm{~K}, 0.0 \% \mathrm{Mg}, 0.0 \% \mathrm{~S}, 138 \mathrm{IU} / \mathrm{kg}$ of vitamin $\mathrm{A}, 13.2 \mathrm{IU} / \mathrm{kg}$ of vitamin $\mathrm{D}, 68.1 \mathrm{mg} / \mathrm{kg}$ of vitamin $\mathrm{E}$.

${ }^{3}$ Salt equivalent calculated by using $\mathrm{NRC}$ values for $\mathrm{Na}$ and $\mathrm{Cl}$ in feed ingredients, with $\mathrm{Cl}$ as the base.

change significantly when heifers were relocated to individual stalls and catheterized.

All excreted urine was weighed and a subsample (130 $\mathrm{mL}$ of urine) was collected every $6 \mathrm{~h}$. Remaining urine was acidified to below pH 2 by using $7.7 \mathrm{~mL}$ of $2 \mathrm{~N}$ $\mathrm{H}_{2} \mathrm{SO}_{4} / \mathrm{kg}$ of urine every $6 \mathrm{~h}$, pooled, and sampled after $24 \mathrm{~h}$. Acidified urine was frozen and stored for later analysis (described below). Unacidified subsamples were analyzed immediately as required for total suspended solids (TSS) and volatile suspended solids (VSS; described below). All excreted feces were collected, stored in a sealed container, weighed, mixed, and subsampled after $24 \mathrm{~h}$. One subsample per heifer was frozen for later analysis, and one sample per heifer was analyzed immediately (described below). Feed refusals were weighed daily, and feed and refusal samples were collected on d 5 of each collection period. Body weight, BCS, wither height, and hip height were recorded for 2 consecutive days before the beginning of each collection period. Initial BW, BCS, and stature measures were taken at the end of the 2 -wk adaptation period when each heifer started the study. Each time, heifers were measured from the front left hoof to the top of the withers for wither height, from the rear left hoof to the top of the hip for hip height, and from the 
center of the left hip laterally across to the center of the right hip for hip width with a cloth measuring tape. Body condition score was assessed on a scale of 1 to 5 by 2 trained personnel by using the system of Wildman et al. (1982).

\section{Laboratory Analysis}

Feed, refusals, and fecal samples were dried at $60^{\circ} \mathrm{C}$ to a constant weight and then ground through a 1-mm screen in a Wiley mill (Arthur H. Thomas, Philadelphia, PA). These samples were analyzed in duplicate for $\mathrm{Ca}$, $\mathrm{P}$, and total Kjeldahl N (AOAC, 1984). Feed and refusals were analyzed sequentially for NDF and ADF according to Van Soest et al. (1991), with the addition of $\alpha$-amylase in the initial wash. Feces samples were analyzed by using the same method without $\alpha$-amylase in the initial wash. Urine samples were analyzed for $\mathrm{Ca}$ and $\mathrm{P}$ according to standard methods (AOAC, 1984). Urine samples were analyzed in duplicate for total Kjeldahl N, urea N, TSS, VSS, and chemical oxygen demand (COD; AOAC, 1984; American Public Health Association, 1998). Feces samples were also analyzed for TSS, VSS, and COD. Total solids content of manure is directly related to turbidity, and consists of both suspended and dissolved material. Volatile solids (VS) are a measure of the organic component of TS. Total suspended solids and VSS are the solids in water that can be trapped by a filter (particulates). Chemical oxygen demand is a measure of the amount of oxygen required to completely oxidize all the organics.

\section{Statistical Analysis}

The effect of diet on measures of growth and nutrient utilization was analyzed by using the RANDOM and REPEATED statements of PROC MIXED of SAS. Effects of treatment, heifer, group, period or day, and the interaction of treatment and group were represented by the model:

$$
\mathrm{Y}=\mu+\mathrm{T}_{\mathrm{i}}+\mathrm{G}_{\mathrm{j}}+\mathrm{H}_{\mathrm{k}(\mathrm{ij})}+\mathrm{P}_{1}+\mathrm{TG}_{(\mathrm{ij})}+\mathrm{E}_{\mathrm{ijk} \mathrm{l}},
$$

where $\mu$ is the overall population mean; $T_{i}$ is the effect of the ith diet ( $i=1,2,3$; fixed); $G_{j}$ is the effect of the jth group $\left(\mathrm{j}=1,2,3\right.$; fixed); $\mathrm{H}_{\mathrm{k}(\mathrm{ij})}$ is the effect of the kth heifer within group and diet $(\mathrm{k}=1,2,3, \ldots 6$; random); $P_{1}$ is the effect of the lth period $(1=1,2,3,4$; fixed); $\mathrm{TG}_{(\mathrm{ij})}$ is the interaction of diet and group; and $\mathrm{E}_{\mathrm{ijkl}}$ is the residual error term (random).

Preplanned contrasts were used to compare the average of $\mathrm{HF}$ and $\mathrm{BP}$ vs. $\mathrm{LF}$ and $\mathrm{HF}$ vs. BP. Because the contrasts evaluated were not orthogonal, values were tested by using the Bonferroni method. Data are re- ported as LS means and differences were declared significant at $P<0.05$. Trends were declared significant at $P<0.10$.

\section{Comparison with American Society of Agricultural and Biological Engineers Standards}

Prediction equations from the new Manure Production and Characteristics Standards [American Society of Agricultural and Biological Engineers (ASABE), 2005] were used to compare the data from this study with the predicted values. Individual heifer observations from each period from the current data set were used, and the difference between actual and predicted values was calculated. Regression analysis was done to compare observed and predicted values from both dairy and beef equations for manure, $\mathrm{N}$, and $\mathrm{P}$ excretion. The following equations from Section 4.0 Equations for AsExcreted Manure Characteristic Estimates for Beef Cattle and Section 5.0 Equations for As-Excreted Manure Characteristics for Dairy Cattle were evaluated.

Beef standard equations:

$$
\begin{aligned}
{[4.3 .1-1] \mathrm{DM}_{\mathrm{E}} } & =[\mathrm{DMI} \times(1-\mathrm{DMD} / 100)] \\
& +20.3 \times(0.06 \times \mathrm{BW})]
\end{aligned}
$$

[4.3.2-3] $\mathrm{OM}_{\mathrm{E}}=[\mathrm{DMI} \times(1-\mathrm{ASH} / 100) \times(1-\mathrm{OMD} / 100)$

$$
+17 \times(0.06 \times \mathrm{BW})]
$$

$$
\begin{gathered}
{[4.3 .3-5] \mathrm{N}_{\mathrm{E}-\mathrm{T}}=\left[\Sigma_{\mathrm{x}=1}^{\mathrm{n}}\left(\mathrm{DMI}_{\mathrm{x}} \times \mathrm{C}_{\mathrm{cp}-\mathrm{x}} \times \mathrm{DOF}_{\mathrm{x}} / 6.25\right)\right.} \\
-\left[41.2 \times\left(\mathrm{BW}_{\mathrm{f}}-\mathrm{BW}_{\mathrm{i}}\right)\right]+\left\{0.243 \times \mathrm{DOF}_{\mathrm{T}}\right. \\
\left.\times\left[\left(\mathrm{BW}_{\mathrm{f}}+\mathrm{BW}_{\mathrm{i}}\right) / 2\right]^{0.75} \times\left[\mathrm{SRW} / \mathrm{BW}_{\mathrm{f}} \times 0.96\right)\right]^{0.75} \times\left[\left(\mathrm{BW}_{\mathrm{f}}\right.\right. \\
\left.\left.\left.-\mathrm{BW}_{\mathrm{i}}\right) / \mathrm{DOF}_{\mathrm{T}}\right]^{1.097}\right\} \\
{[4.3 .4-6] \mathrm{P}_{\mathrm{E}-\mathrm{T}}=\Sigma_{\mathrm{x}=1}^{\mathrm{n}}\left(\mathrm{DMI}_{\mathrm{x}} \times \mathrm{C}_{\mathrm{p}-\mathrm{x}} \times \mathrm{DOF}_{\mathrm{x}}\right)} \\
-\left[10.0 \times\left(\mathrm{BW}_{\mathrm{f}}-\mathrm{BW}_{\mathrm{i}}\right)\right]+\left\{5.92 \times 10^{-2} \times \mathrm{DOF}_{\mathrm{T}}\right. \\
\left.\times\left[\left(\mathrm{BW}_{\mathrm{f}}+\mathrm{BW}_{\mathrm{i}}\right) / 2\right]^{0.75} \times\left[\mathrm{SRW} / \mathrm{BW}_{\mathrm{f}} \times 0.96\right)\right]^{0.75} \\
\left.\times\left[\left(\mathrm{BW}_{\mathrm{f}}-\mathrm{BW}_{\mathrm{i}}\right) / \mathrm{DOF}_{\mathrm{T}}\right]^{1.097}\right\}
\end{gathered}
$$

where $\mathrm{DM}_{\mathrm{E}}$ is the $\mathrm{DM}$ excretion per animal per day; $\mathrm{OM}_{\mathrm{E}}$ is the $\mathrm{OM}$ excretion per animal per day; $\mathrm{N}_{\mathrm{E}-\mathrm{T}}$ is the total $\mathrm{N}$ excretion per finished animal; $\mathrm{P}_{\mathrm{E}-\mathrm{T}}$ is the total $\mathrm{P}$ excretion per finished animal; $\mathrm{DOF}_{\mathrm{T}}$ is the day on feed where $\mathrm{T}$ is the total days on feed and $\mathrm{x}$ is a ration number; $\mathrm{BW}_{\mathrm{f}}$ is the final $\mathrm{BW}$; $\mathrm{BW}_{\mathrm{i}}$ is the initial $\mathrm{BW}$; SRW is the standard reference weight for expected final body fat $(478 \mathrm{~kg}) ; \mathrm{C}_{\mathrm{cp}-\mathrm{x}}$ is the concentration of $\mathrm{CP}$ in the ration $\mathrm{x} D \mathrm{DM}$; and $\mathrm{C}_{\mathrm{p}-\mathrm{x}}$ is the concentration of $\mathrm{P}$ in ration $\mathrm{x}$. 
Table 2. Dry matter intake, digestibility, and manure production in Holstein heifers fed diets varying in forage content

\begin{tabular}{|c|c|c|c|c|c|c|}
\hline \multirow[b]{3}{*}{ Item } & \multirow{2}{*}{\multicolumn{3}{|c|}{ Dietary treatment ${ }^{1}$}} & \multirow[b]{3}{*}{$\mathrm{SEM}^{2}$} & \multicolumn{2}{|c|}{$P<$} \\
\hline & & & & & \multirow{2}{*}{$\begin{array}{l}\mathrm{HF} \text { and } \\
\text { BP vs. } \mathrm{LF}^{3}\end{array}$} & \multirow[b]{2}{*}{$\mathrm{HF}$ vs. $\mathrm{BP}^{4}$} \\
\hline & $\mathrm{HF}$ & BP & $\mathrm{LF}$ & & & \\
\hline DMI, kg/d & 8.93 & 8.28 & 7.65 & 0.06 & 0.01 & 0.01 \\
\hline Apparent DM digestibility, \% & 58.7 & 61.8 & 67.2 & 1.10 & 0.01 & 0.11 \\
\hline OM intake, $\mathrm{kg} / \mathrm{d}$ & 8.29 & 7.60 & 7.08 & 0.18 & 0.01 & 0.03 \\
\hline OM digestibility, \% & 60.3 & 62.8 & 68.2 & 0.01 & 0.01 & 0.16 \\
\hline $\mathrm{ME}$ intake,${ }^{5} \mathrm{Mcal} / \mathrm{d}$ & 20.8 & 19.4 & 21.3 & 2.06 & 0.83 & 0.83 \\
\hline \multicolumn{7}{|l|}{ Feces } \\
\hline $\mathrm{kg}$ of $\mathrm{DM} / \mathrm{d}$ & 3.61 & 3.16 & 2.54 & 0.08 & 0.01 & 0.01 \\
\hline $\mathrm{kg}$ of wet manure/d & 22.4 & 17.9 & 15.3 & 0.73 & 0.01 & 0.01 \\
\hline \multicolumn{7}{|l|}{ Urine } \\
\hline $\mathrm{kg} / \mathrm{d}$ & 8.92 & 16.9 & 40.2 & 5.50 & 0.01 & 0.35 \\
\hline \multicolumn{7}{|l|}{ Total manure } \\
\hline $\mathrm{kg}$ of wet/d & 31.3 & 34.8 & 55.5 & 6.2 & 0.03 & 0.71 \\
\hline
\end{tabular}

Dairy standard equations:

$$
\begin{gathered}
{[5.3 .3-5] \mathrm{M}_{\mathrm{E}}=(\mathrm{DMI} \times 3.886)-(\mathrm{BW} \times 0.029)+5.641} \\
{[5.3 .0-19] \mathrm{N}_{\mathrm{E}}=\left(\mathrm{DMI} \times \mathrm{C}_{\mathrm{cp}} \times 78.390\right)+51.350} \\
\left.[5.3 .12-24] \mathrm{P}_{\mathrm{E}}=(\mathrm{DMI} \times 1000) \times \mathrm{C}_{\mathrm{p}}\right)
\end{gathered}
$$

where $\mathrm{M}_{\mathrm{E}}$ is the total wet manure excretion per animal per day; $\mathrm{N}_{\mathrm{E}}$ is the total $\mathrm{N}$ excretion per animal per day; $\mathrm{P}_{\mathrm{E}}$ is the total $\mathrm{P}$ excretion per animal per day; $\mathrm{C}_{\mathrm{cp}}$ is the concentration of $\mathrm{CP}$ in the ration $\mathrm{DM}$; and $\mathrm{C}_{\mathrm{p}}$ is the concentration of $\mathrm{P}$ in the ration DM.

\section{RESULTS AND DISCUSSION}

\section{Diet Composition, Intake, and Growth Measures}

The $\mathrm{LF}$ ration was higher in $\mathrm{CP}$ than $\mathrm{HF}$ and $\mathrm{BP}$, and was much lower in NDF and ADF concentrations (Table 1). Calcium concentration did not change when forage content was decreased; however, $\mathrm{P}$ concentration was higher in the LF ration compared with the $\mathrm{HF}$ and $\mathrm{BP}$ rations ( 0.41 vs. 0.29 ; Table 1 ). Adding by-product feeds (cottonseed hulls and soybean hulls) decreased the NDF concentration but increased ADF (36.3 vs. $39.5 \%$ ). The addition of cottonseed hulls to the $\mathrm{BP}$ ration was likely responsible for the increase in ADF. Calcium concentration also increased with the addition of byproducts; however, $\mathrm{P}$ concentration was not affected by BP inclusion (Table 1).

The NRC (2001) model predicts DMI to be $11.8 \mathrm{~kg} / \mathrm{d}$ in heifers fed HF and BP and $11.2 \mathrm{~kg} / \mathrm{d}$ in heifers fed
LF. In this study, initial feed offered to heifers was based on this prediction and feed was always available ad libitum, but heifers fed HF consumed only $8.93 \mathrm{~kg} /$ $\mathrm{d}$; therefore, heifers fed $\mathrm{BP}$ and LF also consumed less than predicted (NRC, 2001; Table 1). Actual DMI of heifers fed LF was $86 \%$ of that of heifers fed HF. Diets were equal in ME intake, as designed $(20.5 \mathrm{mcal} / \mathrm{d}$; Table 2). Organic matter intake was also higher in heifers fed HF compared with BP and lower in heifers fed LF compared with $\mathrm{HF}$ and BP.

There were no significant differences in growth measures with dietary treatment (Table 3 ). There was a trend for a higher feed-to-gain ratio in heifers fed $\mathrm{HF}$ and BP compared with those fed LF (19.5 vs. $15.1 ; P<$ $0.09)$. In addition, feed to gain tended to be higher in heifers fed the HF diet compared with those fed BP (21.8 vs. $17.1 ; P<0.09$ ). Average daily gains in these heifers were not affected by treatment, and were lower than expected. The NRC (2001) predicted 0.65, 0.51, and $0.85 \mathrm{~kg} / \mathrm{d}$ of gain in heifers fed the HF, BP, and LF rations when DMI was set to $8.93,8.28$, and 7.65 , respectively. These heifers were gaining $85 \%$ of the predicted values while consuming only $73 \%$ of the DMI predicted by NRC (2001) for this age group. The authors assume that ADG could have been increased with increased DMI. Average BW (kg) of these heifers (521 kg) closely matched the values reported by Heinrichs and Losinger (1998) in a nationwide survey of dairy heifer growth $(515 \mathrm{~kg})$. Possible negative effects on growth rates are a major concern with limit feeding heifers. In this study, there was neither a positive nor a negative 
Table 3. Body weight and measures in growing Holstein heifers fed diets varying in forage content

\begin{tabular}{|c|c|c|c|c|c|c|}
\hline \multirow[b]{3}{*}{ Item } & \multirow{2}{*}{\multicolumn{3}{|c|}{ Dietary treatment ${ }^{1}$}} & \multirow[b]{3}{*}{$\mathrm{SEM}^{2}$} & \multicolumn{2}{|c|}{$P<$} \\
\hline & & & & & HF and & \\
\hline & $\mathrm{HF}$ & $\mathrm{BP}$ & $\mathrm{LF}$ & & BP vs. $\mathrm{LF}^{3}$ & $\mathrm{HF}$ vs. $\mathrm{BP}^{4}$ \\
\hline $\mathrm{BW}$ gain, ${ }^{5} \mathrm{~kg}$ & 58.8 & 54.1 & 57.7 & 7.59 & 0.90 & 0.69 \\
\hline Average daily gain, $\mathrm{kg} / \mathrm{d}$ & 0.57 & 0.52 & 0.56 & 0.07 & 0.91 & 0.66 \\
\hline Feed:gain & 21.8 & 17.1 & 15.1 & 1.66 & 0.09 & 0.09 \\
\hline Wither height, cm & 136 & 136 & 136 & 0.81 & 0.29 & 0.73 \\
\hline$\Delta$ Wither height, ${ }^{5} \mathrm{~cm}$ & 1.85 & 1.52 & 1.60 & 0.97 & 0.94 & 0.82 \\
\hline Hip height, cm & 141 & 140 & 138 & 0.99 & 0.16 & 0.61 \\
\hline$\Delta$ Hip height, ${ }^{5} \mathrm{~cm}$ & -0.68 & -0.38 & 0.56 & 0.99 & 0.41 & 0.84 \\
\hline $\mathrm{BCS}$ & 3.31 & 3.29 & 3.26 & 0.35 & 0.27 & 0.38 \\
\hline
\end{tabular}

${ }^{1} \mathrm{HF}=$ high forage $\mathrm{BP}=$ by-product; $\mathrm{LF}=$ low forage.

${ }^{2} \mathrm{n}=18$.

${ }^{3}$ High forage and by-product diet vs. low forage diet.

${ }^{4}$ High forage vs. by-product diet.

${ }^{5}$ Means calculated by final - initial over entire study.

effect on growth rates when heifers were limit fed an $\mathrm{LF}$ ration.

\section{Digestibility and Manure Excretion}

Apparent DM digestibility and OM digestibility were higher in heifers fed the LF ration compared with those fed the $\mathrm{HF}$ and $\mathrm{BP}$ rations. Heifers fed the LF ration excreted $0.75 \mathrm{~kg}$ less fecal DM/d compared with those fed the HF and BP rations (Table 2). Dry matter digestibility was not different between heifers fed HF and BP.

An $11 \%$ reduction in DMI along with an increase in apparent DM digestibility resulted in a $25 \%$ decrease in fecal output for BP heifers compared with HF heifers. Driedger and Loerch (1999) noticed a similar trend when dry cows were limit fed a low-fiber diet. These authors restricted intake in the cows fed the low-fiber ration by $29 \%$ compared with other cows fed a highfiber ration and noted a $40 \%$ reduction in fecal excretion. Heifers fed the BP ration excreted less feces $(\mathrm{kg}$ of $\mathrm{DM} / \mathrm{d}$ ) than those fed the HF ration.

There were no differences in urinary output or total manure excretion for heifers fed HF vs. BP (Table 2). Urinary output was much higher in heifers fed LF compared with those fed HF and BP. Heifers fed the LF ration increased urinary output by 3 -fold compared with heifers fed HF and BP. Because of the increase in urinary output in heifers fed LF, the total weight of manure excreted was also higher. The increase in urinary output may be the result of differences in diet digestibility or behavioral impacts of limit feeding. Johnson and Combs (1991) noted that feeding a highenergy diet to multiparous cows during the prepartum period increased water intake from 104 to $127 \mathrm{~kg} / \mathrm{d}$. The LF ration from the current study is comparable to the high-energy ration fed by Johnson and Combs
(1991), and if the assumption of increased water intake is made in the heifers fed LF, then the increase in urinary output would be expected (Murphy, 1992). Increased water intake is also commonly an effect of increased salt intake. Salt intake (salt equivalent calculated based on $\mathrm{NRC} \mathrm{Na}$ and $\mathrm{Cl}$ values for feed ingredients) was low for all treatments and not apparently associated with urine volume.

Alternatively, heifers fed the LF ration may have consumed water to increase rumen fill. Robert et al. (1993) noted that sows fed a mainly corn and soybean meal diet spent twice as much time drinking water compared with those fed higher fiber diets. Heifers fed LF consumed their allotted daily ration by the time rations were mixed and delivered for heifers fed $\mathrm{HF}$ and BP (approximately 45 to $60 \mathrm{~min}$ ). It seems logical that they may have consumed more water to replace the typical bulk of the HF ration.

A final possible explanation for the increased urinary output on the LF diet is behavioral. Although published research linking limit feeding to altered behavior in dairy cattle is scarce, it is logical that rapid consumption of the day's DM, as a side effect of limit feeding, may lead to an increase in drinking and other oral behaviors (Lawrence et al., 1993). Field observations suggest that limit feeding increases vocalization and stereotypies (repetitive patterns of movement or behavior). Drinking water is often measured as a stereotypy, and Terlouw et al. (1993) showed that limit feeding nulliparous sows led to an increase in drinking activity. In addition, Hoffman et al. (2006) noted that limit-fed heifers, similar to those in this study, spent less time eating, spent more time standing without eating, and vocalized more than heifers fed an ad libitum ration. 
Table 4. Nitrogen digestibility, excretion, and retention in Holstein heifers fed diets with varying forage content

\begin{tabular}{|c|c|c|c|c|c|c|}
\hline \multirow[b]{3}{*}{ Item } & \multirow{2}{*}{\multicolumn{3}{|c|}{ Dietary treatment ${ }^{1}$}} & \multirow[b]{3}{*}{$\mathrm{SEM}^{2}$} & \multicolumn{2}{|c|}{$P<$} \\
\hline & & & & & \multirow{2}{*}{$\begin{array}{l}\text { HF and } \\
\text { BP vs. LF }\end{array}$} & \multirow[b]{2}{*}{ HF vs. $\mathrm{BP}^{4}$} \\
\hline & $\mathrm{HF}$ & $\mathrm{BP}$ & $\mathrm{LF}$ & & & \\
\hline $\mathrm{N}$ intake, g/d & 194 & 185 & 218 & 1.43 & 0.01 & 0.01 \\
\hline $\mathrm{N}$ digestibility, $\%$ & 60.8 & 59.4 & 73.2 & 1.10 & 0.01 & 0.41 \\
\hline \multicolumn{7}{|l|}{ Fecal N } \\
\hline $\mathrm{g} / \mathrm{d}$ & 74.2 & 74.8 & 57.8 & 1.69 & 0.01 & 0.80 \\
\hline \multicolumn{7}{|l|}{ Urine $\mathrm{N}$} \\
\hline $\mathrm{g} / \mathrm{d}$ & 87.5 & 87.7 & 111 & 9.76 & 0.07 & 0.98 \\
\hline$\%$ of $\mathrm{N}$ intake & 46.4 & 49.0 & 53.8 & 5.10 & 0.35 & 0.72 \\
\hline Urinary urea N & 67.4 & 50.6 & 56.0 & 15.7 & 0.89 & 0.46 \\
\hline \multicolumn{7}{|l|}{ Total N excretion } \\
\hline$\%$ of $\mathrm{N}$ intake & 85.6 & 89.6 & 80.6 & $\begin{array}{l}0.00 \\
4.30\end{array}$ & 0.21 & 0.52 \\
\hline \multicolumn{7}{|l|}{$\mathrm{N}$ retention } \\
\hline $\mathrm{g} / \mathrm{d}$ & 32.6 & 22.7 & 49.8 & 8.23 & 0.04 & 0.40 \\
\hline$\%$ of $\mathrm{N}$ intake & 14.4 & 10.3 & 19.3 & 4.30 & 0.21 & 0.52 \\
\hline
\end{tabular}

${ }^{1} \mathrm{HF}=$ high forage; $\mathrm{BP}=$ by-product; $\mathrm{LF}=$ low forage.

${ }^{2} \mathrm{n}=18$.

${ }^{3}$ High forage and by-product diet vs. low forage diet.

${ }^{4}$ High forage vs. by-product diet.

\section{Nitrogen Intake, Excretion, and Partitioning}

Nitrogen intake was greater in heifers fed the LF ration compared with those fed $\mathrm{HF}$ and $\mathrm{BP}$ (Table 4). Apparent $\mathrm{N}$ digestibility was higher in heifers fed LF compared with $\mathrm{HF}$ and $\mathrm{BP}$, and fecal excretion of $\mathrm{N}$ was lower. This was similar to the observation of Zanton et al. (2006), who observed an improvement in apparent $\mathrm{N}$ digestibility in heifers fed a $25 \%$ forage ration compared with $75 \%$ forage, and a trend for lower fecal $\mathrm{N}$ excretion. Nitrogen in the feces is primarily nucleic acids and bacterial protein produced in the lower bowel. Increases in bacterial protein production in the hindgut with the higher fiber diets ( $\mathrm{HF}$ and $\mathrm{BP}$ ) would be expected if ruminal DM digestibility is reduced (that is, more DM passes to the lower tract) and total tract retention time is increased (more time for fermentation in the lower gut) on these diets compared with the highgrain diet.

The additional $\mathrm{N}$ consumed by heifers fed LF was excreted in urine (111 vs. $87.6 \mathrm{~g}$ of $\mathrm{N} / \mathrm{d}, P<0.07)$ and some was retained ( 49.8 vs. $27.7 \mathrm{~g}$ of $\mathrm{N} / \mathrm{d}$ ), but partitioning of absorbed $\mathrm{N}$ was not different. Zanton et al. (2006) noted no difference in urinary $\mathrm{N}$ excretion when heifers were fed rations with either 25 or $75 \%$ forage. Both Marini and Van Amburgh (2003) and Gabler and Heinrichs (2003) reported increasing $\mathrm{N}$ excretion with increased $\mathrm{N}$ intake entirely because of increased urinary $\mathrm{N}$ excretion; no differences in fecal $\mathrm{N}$ excretion were observed in those studies. Urinary $\mathrm{N}$ as a percentage of $\mathrm{N}$ intake, urinary urea $\mathrm{N}$, and total $\mathrm{N}$ excretion
( $\mathrm{g} / \mathrm{d}$ and percentage of $\mathrm{N}$ intake) were not affected by fiber level ( $\mathrm{HF}$ and $\mathrm{BP}$ vs. $\mathrm{LF}$ ).

Contradictory to the design, heifers consuming the $\mathrm{HF}$ ration had higher $\mathrm{N}$ intake than those fed $\mathrm{BP}$, which was a result of lower DMI in heifers fed BP compared with HF. No differences were observed in $\mathrm{N}$ digestibility or in fecal, urinary, or total excretion of $\mathrm{N}$ when byproducts were added to the diet (HF vs. BP; Table 4). Total $\mathrm{N}$ retention was also not different in heifers fed HF compared with those fed BP.

\section{$P$ Intake, Excretion, and Partitioning}

Phosphorus intake was not affected by treatment (Table 5). The LF ration was higher in $\mathrm{P}$ (\% of DM) compared with HF and BP, but DMI of heifers fed LF was less than that of heifers fed $\mathrm{HF}$ and BP, leaving no significant difference in $\mathrm{P}$ intake. Phosphorus digestibility was higher in heifers fed LF compared with HF and BP. Phosphorus digestibility in heifers fed HF was less than that of heifers fed BP, and both diets resulted in negative $\mathrm{P}$ digestibility. A 95\% confidence interval of $\mathrm{P}$ digestibility for both $\mathrm{HF}$ and $\mathrm{BP}$ rations included zero, indicating that $\mathrm{P}$ digestibility of these 2 diets was not different from zero. These heifers were excreting essentially all the $\mathrm{P}$ they consumed, and retention was so low as to be undetectable within our study. No data are available on the pregnancy requirements of lategestation heifers, but requirements for $\mathrm{P}$ for mature cows of a comparable stage range from less than $1 \mathrm{~g} / \mathrm{d}$ to less than $6 \mathrm{~g} / \mathrm{d}$ just before calving (NRC, 2001). These 
Table 5. Phosphorus digestibility, excretion, and retention in Holstein heifers fed diets varying in forage content

\begin{tabular}{|c|c|c|c|c|c|c|}
\hline \multirow[b]{3}{*}{ Item } & \multirow{2}{*}{\multicolumn{3}{|c|}{ Dietary treatment ${ }^{1}$}} & \multirow[b]{3}{*}{ SEM } & \multicolumn{2}{|c|}{$P<$} \\
\hline & & & & & \multirow{2}{*}{$\begin{array}{l}\mathrm{HF} \text { and } \\
\text { BP vs. } \mathrm{LF}^{2}\end{array}$} & \multirow[b]{2}{*}{ HF vs. BP } \\
\hline & $\mathrm{HF}$ & $\mathrm{BP}$ & $\mathrm{LF}$ & & & \\
\hline $\mathrm{P}$ intake, $\mathrm{g} / \mathrm{d}$ & 30.0 & 30.9 & 33.1 & 1.6 & 0.17 & 0.68 \\
\hline $\mathrm{P}$ digestibility, \% & -34.1 & -8.4 & 12.6 & 9.2 & 0.01 & 0.05 \\
\hline \multicolumn{7}{|l|}{ Fecal P } \\
\hline $\mathrm{g} / \mathrm{d}$ & 39.4 & 32.5 & 29.4 & 2.9 & 0.08 & 0.11 \\
\hline \multicolumn{7}{|l|}{ Urine $\mathrm{P}$} \\
\hline $\mathrm{g} / \mathrm{d}$ & 0.78 & 1.67 & 4.80 & 0.83 & 0.01 & 0.46 \\
\hline$\%$ intake & 2.79 & 5.64 & 14.9 & 2.7 & 0.01 & 0.47 \\
\hline \multicolumn{7}{|l|}{ Total P excretion } \\
\hline $\mathrm{g} / \mathrm{d}$ & 40.1 & 33.9 & 36.2 & 2.47 & 0.80 & 0.09 \\
\hline$\%$ intake & 134 & 117 & 105 & 2.78 & 0.02 & 0.09 \\
\hline \multicolumn{7}{|l|}{$\mathrm{P}$ retention } \\
\hline $\mathrm{g} / \mathrm{d}$ & -10.4 & -3.58 & -0.55 & 2.5 & 0.04 & 0.06 \\
\hline$\%$ intake & -36.3 & -13.8 & -2.32 & 9.0 & 0.04 & 0.09 \\
\hline
\end{tabular}

${ }^{1} \mathrm{HF}=$ high forage; $\mathrm{BP}=$ by-product; $\mathrm{LF}$ = low forage.

${ }^{2} \mathrm{n}=18$.

${ }^{3}$ High forage and by-product diet vs. low forage diet.

${ }^{4}$ High forage vs. by-product diet.

requirements are likely even lower in the bred heifer, because mature cows are replenishing bone mineral depleted by the demands of the previous lactation. Driedger and Loerch (1999) fed gravid dry cows varying levels of fiber and $\mathrm{P}$ in the diet. These cows were fed at nearly 5 times the $\mathrm{P}$ requirements $(0.95$ to $1.1 \%$ of $\mathrm{DM}$ and 0.25 to $0.30 \%$ of DM, respectively; NRC, 2001) and retained approximately $30 \%$ of the intake $\mathrm{P}$.

Phosphorus requirements for growth in heifers of this BW are estimated as 4 to $5 \mathrm{~g} / \mathrm{d}$ (NRC, 2001), and requirements are poorly defined. In feedlot steers, Erickson et al. (2002) observed no effects of dietary $\mathrm{P}$ as low as $0.16 \%$ of $\mathrm{DM}$ on ADG or bone-breaking strength in finishing feedlot steers. Based on the dietary $\mathrm{P}$ concentrations of 0.3 to $0.4 \%$ of $\mathrm{DM}$, the heifers in the current study were overfed.

Fecal excretion of $\mathrm{P}$ tended to be lower $(P<0.08)$ and urinary $\mathrm{P}$ excretion was higher for LF heifers compared with $\mathrm{HF}$ and $\mathrm{BP}$ heifers. Fecal or urinary excretion of $\mathrm{P}$ was not different between heifers fed HF or BP. Urinary $\mathrm{P}$ excretion is typically minimal in lactating dairy cows, but the heifers fed the LF ration excreted nearly 5 times as much urinary $\mathrm{P}$ as reported for lactating cows (Morse et al., 1992; Knowlton et al., 2001). Total $P$ excretion ( $\mathrm{g} / \mathrm{d}$ ) was not different on an absolute basis; however, as a percentage of $\mathrm{P}$ intake, total $\mathrm{P}$ excretion was lower for LF vs. HF and BP and tended $(P<0.09)$ to be lower for BP than HF. Driedger and Loerch (1999) noticed a similar pattern in nonlactating cows, in which $\mathrm{P}$ excretion was lower as a percentage of intake in cows fed a high-energy diet. Whether our treatment effects were due to reduced fiber content or to increased energy content cannot be determined, because these are con- founded. Very little published data exists concerning P metabolism in heifers. Gabler and Heinrichs (2003) measured $\mathrm{P}$ intake and fecal, urinary, and total $\mathrm{P}$ excretion in 5-mo-old heifers and found no differences with increasing concentrations of protein. In the current study, $\mathrm{P}$ retention was greater for heifers fed LF than for those fed $\mathrm{HF}$ and $\mathrm{BP}$ and tended $(P<0.06)$ to be greater for heifers fed BP than those fed HF. However, total $\mathrm{P}$ retention was negative for all diets ( $\mathrm{g} / \mathrm{d}$ and as a percentage of $\mathrm{P}$ intake), indicating that heifers were excreting more $\mathrm{P}$ than they consumed.

The effect of diet on partitioning and proportional excretion of $\mathrm{P}$ in heifers merits further investigation because of environmental concerns in the dairy industry. We observed that heifers in late gestation are excreting 60 to $70 \%$ as much $\mathrm{P}$ as a lactating cow (Nennich et al., 2005). These results are important, considering the changes in concentrated animal feeding operation regulations to explicitly include stand-alone heifer operations.

\section{Measures of Solids}

Measures of solids (TS, VS, TSS, VSS, and COD) are useful in evaluating water quality, but because the determination of both VS and VSS may include loss of minerals that volatilize during combustion, COD may be a better measure of organic compounds in water (American Public Health Association, 1998). These types of measures are not typically done in manures but are common in municipal waste samples, and are needed in the design of advanced waste treatment systems (anaerobic digestion, nutrient removal, etc.). 
Table 6. Manure characteristics from Holstein heifers fed diets varying in forage content

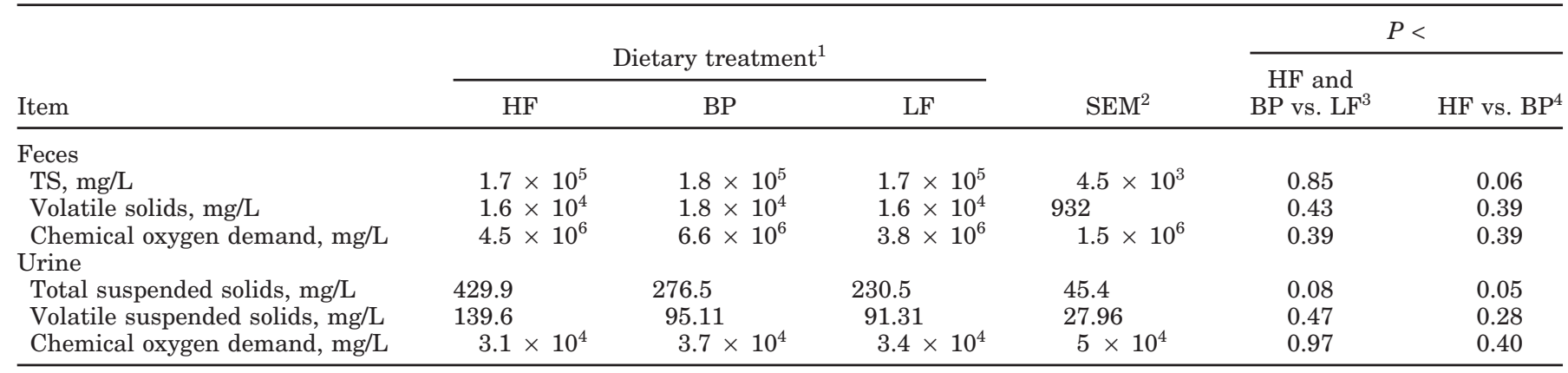

${ }^{1} \mathrm{HF}=$ high forage; $\mathrm{BP}=$ by-product; $\mathrm{LF}=$ low forage.

${ }^{2} \mathrm{n}=18$.

${ }^{3}$ High forage and by-product diet vs. low forage diet.

${ }^{4}$ High forage vs. by-product diet.

These advanced systems are of increasing interest to the dairy industry, making information on the effect of diet on the solids content of manure potentially useful.

We observed no differences in fecal or urinary TS, VS, or VSS concentrations with limit-fed heifers compared with heifers fed high-fiber diets (Table 6). There was a trend for higher TS in feces of heifers fed BP compared with HF. Urinary TSS tended $(P<0.08)$ to be lower for $\mathrm{LF}$ compared with $\mathrm{HF}$ and $\mathrm{BP}$ and were higher for $\mathrm{HF}$ compared with BP. Chemical oxygen demand in the feces and urine was not affected by the addition of by-products.

\section{Comparison with ASABE Prediction Equations}

The dairy standard equations were not good predictors of total wet manure excretion $\left(R^{2}=0.114\right)$ measured in this study. Because heifers fed the LF ration excreted much more urine than normal, the predicted values did not fit the data well. However, the beef standard equations predict total manure excretion on a dry basis, and the values predicted with these beef equations fit the observed values well for total manure excreted $\left(R^{2}=0.556\right)$. Neither the beef nor the dairy equations precisely predicted the $\mathrm{N}$ excretion data $\left(\mathrm{R}^{2}=\right.$ $0.003, \mathrm{R}^{2}=0.0001$, respectively) or $\mathrm{P}$ excretion data $\left(R^{2}=0.038, R^{2}=0.187\right.$; Table 7$)$ observed from this study. Equations that are used for predicting manure DM output are likely inherently more precise than those predicting wet amounts or nutrient content, but additional data are needed to improve the prediction of nutrient excretion by heifers.

\section{CONCLUSIONS}

In this study, heifer growth was not affected when forages were replaced with by-product feeds or concentrates and diets were limit fed to provide similar intakes of ME. Total nutrient excretion did not differ across dietary treatments, but the increase in urinary output in heifers limit fed LF diets could make manure management more difficult. Although heifers limit fed a LF ration excreted greater amounts of urine per day, growth and nutrient utilization were not affected.

In this study, late-gestation heifers had negative $\mathrm{P}$ retention, implying that heifers in late gestation are retaining little or no $\mathrm{P}$ and likely excrete all $\mathrm{P}$ consumed. The current ASABE beef equations that predict manure DM excretion rather than wet manure excretion were better predictors of manure excretion observed in this study. Overall, heifers achieving similar rates of gain from diets differing in forage, grain, and by-product content excreted widely varying quantities of manure.

Table 7. Comparison of observed and predicted values of manure and nutrient excretion using American Society of Agricultural and Biological Engineers (2005) Standards

\begin{tabular}{llll}
\hline Standard & \multicolumn{1}{c}{ Item } & Regression equation & $\mathrm{R}^{2}$ \\
\hline Dairy & Wet manure, $\mathrm{kg} / \mathrm{d}$ & $\mathrm{y}=-0.0894 \mathrm{x}+25.616$ & 0.114 \\
Beef & Manure DM, kg/d & $\mathrm{y}=0.6733 \mathrm{x}+1.342$ & 0.556 \\
Dairy & $\mathrm{N}, \mathrm{g} / \mathrm{d}$ & $\mathrm{y}=-0.0049 \mathrm{x}+148.85$ & 0.0001 \\
Beef & $\mathrm{N}, \mathrm{g} / \mathrm{d}$ & $\mathrm{y}=-0.0326 \mathrm{x}+117.95$ & 0.003 \\
Dairy & $\mathrm{P}, \mathrm{g} / \mathrm{d}$ & $\mathrm{y}=0.1017 \mathrm{x}+23.308$ & 0.187 \\
Beef & $\mathrm{P}, \mathrm{g} / \mathrm{d}$ & $\mathrm{y}=-0.8929 \mathrm{x}+155.2$ & 0.038 \\
\hline
\end{tabular}

${ }^{1} \mathrm{y}=($ observed $) ; \mathrm{x}=($ predicted $)$. 


\section{REFERENCES}

American Public Health Association. 1998. Standard Methods for the Examination of Water and Wastewater. 20th ed. Am. Public Health Assoc., Washington, DC.

American Society of Agricultural and Biological Engineers. 2005. Standard D384.2: Manure Production and Characteristics. Am. Soc. Agric. Biol. Eng., St. Joseph, MI.

AOAC. 1984. Official Methods of Analysis. 14th ed. Assoc. Off. Anal. Chem., Arlington VA.

Davidson, S., B. A. Hopkins, D. E. Diaz, S. M. Bolt, C. Brownie, V. Fellner, and L. W. Whitlow. 2003. Effects of amounts and degradability of dietary protein on lactation, nitrogen utilization, and excretion in early lactation Holstein cows. J. Dairy Sci. $86: 1681-1689$.

Driedger, L. J., and S. C. Loerch. 1999. Limit-feeding corn as an alternative to hay reduces manure and nutrient output by Holstein cows. J. Anim. Sci. 77:967-972.

Erickson, G. E., T. J. Klopfenstein, C. T. Milton, D. Brink, M. W. Orth, and K. M. White. 2002. Phosphorus requirement of finishing feedlot calves. J. Anim. Sci. 80:1690-1695.

Gabler, M. T., and A. J. Heinrichs. 2003. Effects of increasing dietary protein on nutrient utilization in heifers. J. Dairy Sci. 86:2170-2177.

Haig, P. A., T. Mutsvangwa, R. Spratt, and B. W. McBride. 2002. Effects of dietary protein solubility on nitrogen losses from lactating dairy cows and comparison with predictions from the Cornell Net Carbohydrate and Protein System. J. Dairy Sci. 85:12081217.

Heinrichs, A. J. 1993. Raising dairy heifers to meet the needs of the 21st century. J. Dairy Sci. 76:3179-3187.

Heinrichs, A. J., and W. C. Losinger. 1998. Growth of dairy heifers in the United States. J. Anim. Sci. 76:1254-1260.

Hoffman, P., C. Simson, and M. Wattiaux. 2006. The effect of limitfeeding gravid heifers on first lactation milk production. J. Dairy Sci. 89(Suppl. 1):599. (Abstr.)

Johnson, T. R., and D. K. Combs. 1991. Effects of prepartum diet, inert bulk, and dietary polyethylene glycol on dry matter intake of lactating cows. J. Dairy Sci. 74:933-944.

Kebreab, E., J. France, J. A. N. Mills, R. Allison, and J. Dijkstra. 2002. A dynamic model of nitrogen metabolism in the lactating dairy cow and as assessment of impact of nitrogen excretion on the environment. J. Anim. Sci. 80:248-259.

Knowlton, K. F., J. H. Herbein, M. A. Meister-Weisbarth, and W. A. Wark. 2001. Nitrogen and phosphorus partitioning in lactating Holstein cows fed different sources of dietary protein and phosphorus. J. Dairy Sci. 84:1210-1217.
Lawrence, A. B., E. M. Terlouw, and I. Kyriazakis. 1993. The behavioural effects of undernutrition in confined farm animals. Proc. Nutr. Soc. 52:219-229.

Marini, J. C., and M. E. Van Amburgh. 2003. Nitrogen metabolism and recycling in Holstein heifers. J. Anim. Sci. 81:545-552.

Morse, D., H. Head, C. J. Wilcox, H. H. V. Horn, C. D. Hissem, and B. Harris, Jr. 1992. Effects of concentration of dietary phosphorous on amount and route of excretion. J. Dairy Sci. 75:3039-3049.

Murphy, M. R. 1992. Water metabolism of dairy cattle. J. Dairy Sci. 75:326-333.

Nennich, T. D., J. H. Harrison, W. M. Van Wieringen, D. Meyer, A. J. Heinrichs, W. P. Weiss, N. R. St-Pierre, R. L. Kincaid, D. L. Davidson, and E. Block. 2005. Prediction of manure and nutrient excretion from dairy cattle. J. Dairy Sci. 88:3721-3722.

NRC. 2001. Nutrient Requirements of Dairy Cattle. 7th rev. ed. Natl. Acad. Sci, Washington, DC.

Robert, S., J. J. Matte, C. Farmer, C. L. Girard, and G. P. Martineau. 1993. High-fibre diets for sows: Effects on stereotypies and adjunctive drinking. Appl. Anim. Behav. Sci. 37:297-309.

St-Pierre, N. R., and C. S. Threan. 1999. Animal grouping strategies, sources of variation, and economic factors affecting nutrient balance on dairy farms. J. Dairy Sci. 82(Suppl. 2):72-83.

Terlouw, E. M. C., A. B. Lawrence, J. M. Koolhaas, and M. Cockram. 1993. Relationship between feeding, stereotypies, and plasma glucose concentration in food-restricted and restrained sows. Physiol. Behav. 54:189-193.

US Environmental Protection Agency. 2002. Concentrated animal feeding operations clean water act requirements: What are the federal requirements for dairy cow and heifer CAFOs? 833-F-02009. EPA, Washington, DC.

Van Soest, P. J., J. B. Robertson, and B. A. Lewis. 1991. Symposium: Carbohydrate methodology, metabolism, and nutritional implication in dairy cattle. Methods for dietary fiber, neutral detergent fiber, and nonstarch polysaccharides in relation to animal nutrition. J. Dairy Sci. 74:3583-3597.

Wildman, E. E., G. M. Jones, P. E. Wagner, R. L. Boman, H. F. Trout, and T. N. Lesch. 1982. A dairy cow body condition scoring system and its relationship to selected production variables in high producing lactating Holstein cattle. J. Dairy Sci. 65:495-501.

Zanton, G. I., and A. J. Heinrichs. 2006. The effects of restricted feeding a high concentrate or high forage ration for similar weight gain and structural growth in Holstein heifers. J. Dairy Sci. 89(Suppl. 1):211. (Abstr.)

Zanton, G. I., A. J. Heinrichs, and E. F. Wheeler. 2006. The effects of restricted feeding a high concentrate or high forage ration on nutrient digestibility and nitrogen utilization in dairy heifers. J. Dairy Sci. 89(Suppl. 1):598. (Abstr.) 